\title{
An Evaluation of Household Country Food Use in Makkovik, Labrador, July 1980-June 1981
}

\author{
M.G. ALTON MACKEY ${ }^{1}$ and R.D. ORR
}

(Received 3 May 1985; accepted in revised form 9 October 1986)

\begin{abstract}
Country food and wild food are the terms used by the people of the Labrador coast to describe the game fish and plants they obtain themselves. Country food continues to be important to the economic, physical and social well-being of the families in the communities on the Labrador coast. This study was designed to investigate the supply of country food to Makkovik, Labrador, population 333, during one food cycle from 2 July 1980 to 31 June 1981. This paper outlines the quantities of species harvested, the variations in household use and the apparent per capita consumption patterns.

During the study year from July 1980 to June 1981, Makkovik households harvested a total of $28397 \mathrm{~kg}$ of country mammals, fish and birds and 832 $\mathrm{kg}$ of berries from their environment. Caribou rangifer tarandus, Linnaeus, contributed the largest quantity of country food, $10960 \mathrm{~kg}$. Fish harvests amounted to $8574 \mathrm{~kg}$ and wildfowl harvests provided $5334 \mathrm{~kg}$. The quantity of seals recorded during the study year was $3170 \mathrm{~kg}$. This amount appears to be an underestimate of the expected level of harvest by the community. Other marine and land mammals did not contribute greatly to the local economy during the study year.

Forty-three percent of participating households harvested $455 \mathrm{~kg}$ or more during the study year. These households represented $54 \%$ of the population and provided two-thirds of the total quantity of country food harvest. The community harvest of caribou, seals, birds and fish is not evenly distributed among households. Thirty-two percent of households had little or no access to caribou and $13 \%$ reported no seals. Fish and birds were more evenly distributed.

People resident in 30 of the 61 households, representing $44 \%$ of the population, reported a per capita volume of country meat, fish and birds close to or above the national average per capita consumption for all meat, fish and poultry. Four households with $6 \%$ of the population harvested less than $25 \mathrm{~kg}$ per person and two households harvested more than 250 per capita.
\end{abstract}

Key words: country food harvest, indigenous foods, northern economy, Labrador

RÉSUMÉ. C'est par l'expression "nourriture sauvage" que les habitants de la côte du Labrador désignent le gibier, les poissons et les plantes qu'ils se procurent eux-mêmes. La nourriture sauvage continue de jouer un rôle important dans le bien-être économique, physique et social des familles des localités situées sur la côte du Labrador. L'objectif de cette enquête était d'étudier l'approvisionnement en nourriture sauvage de Makkovik Labrador, 333 habitants, au cours d'un cycle alimentaire allant du 2 juillet 1980 au 31 juin 1981 . Cette étude donne un aperçu des quantités d'espèces recueillies, des variations au niveau de la consommation de chaque foyer et les modes de consommation par habitant.

Au cours de l'année d'étude, soit de juillet 1980 à juin 1981, les foyers de Makkovik ont amassé 28397 kilos de mammifères de campagne, de poissons et d'oiseaux ainsi que 832 kilos de baies dans leur milieu. C'est le caribou Rangifer tarandus, Linnaeus, qui a constitué la plus grande quantité de nourriture sauvage, soit 10960 kilos. Les prises de poissons se sont élevées à 8574 kilos et celles d'oiseaux sauvages à 5334 kilos. La quantité de phoques capturés durant l'année d'étude s'est élevée à 3170 kilos. Cette quantité semble être une sous-estimation du niveau prévu par la localité. Les autres mammiferes marins et terrestres n'ont pas beaucoup contribue à l'économie locale durant l'année d'étude.

Quarante trois pour cent des foyers participants ont recueilli au minimum 455 kilos durant l'année d'étude. Ces foyers représentent $54 \%$ de la population et les quantités de nourriture recoltées par eux représentent les deux tiers du total des récoltes. Les prises de caribous, de phoques, d'oiseaux et de poissons ne sont pas réparties de manière égale entre les foyers. Trente-deux pour cent des foyers avaient un accès limité ou nul aux caribous et 13\% on signalé la capture d'aucun phoque. Les prises d'oiseaux et de poissons étaient plus équitablement distribuées.

Les membres de 30 des 61 foyers représentant $44 \%$ de la population on fait état d'un volume de viande, de poisson et de volaille par tête à peu près égal ou supérieur à la moyenne nationale pour toute la viande, le poisson et la volaille. Quatre foyers, soit $6 \%$ de la population ont recueilli moins de 25 kilos par personne et deux foyers ont amassé plus de 250 kilos par tête.

Mots clés: nourriture sauvage, aliments indigènes, économie nordique, Labrador

\section{INTRODUCTION}

For generations the people of the Labrador coast have relied upon the harvesting of wildlife on the land and in the sea for much of their food supply. Each season brings a variety of animal species to the region to feed, breed or rest while on migration, and the people orient their hunting activities and consumption of game to these seasonal changes. The relative abundance or scarcity of game affects the overall economic well-being of the community. Access to country food - or wild food, the term residents use for game they obtain themselves - continues to be important not only to the economy but also to the health and social well-being of families.

While Labrador residents have traditionally harvested game, fish, birds and plants for food, no estimates have been available of the household and community consumption of country food or of the dietary value of these resources. This study was designed to investigate the supply of country food to Makkovik,
Labrador, during one food cycle. It is part of a larger study of imported and country food use in selected coastal Labrador communities.

\section{METHODOLOGY}

The country food use by household was tabulated weekly from 2 July 1980 to 31 June 1981 on a calendar diary by the fieldworker in consultation with the representatives of the household. Estimates of the weight of each species (fish, birds, seal, etc.) harvested for consumption by the participating household were recorded in avoir dupois weights, with the exception of birds and rabbits, which were occasionally noted by the number caught. These numbers were converted to pound values on the basis of weights for the specific birds or mammals recorded on the Labrador coast provided by officials of the provincial Department of Wildlife. Country food acquired as a gift (or purchased from another household) was recorded on the

\footnotetext{
${ }^{1}$ School of Dietetics and Human Nutrition, Macdonald College of McGill University, 21,111 Lakeshore Road, Ste. Anne de Bellevue, P.Q., Canada H9X $1 \mathrm{CO}$

(CThe Arctic Institute of North America
} 
diary of the consuming household. The producing household also recorded the quantity and to whom the food was given. This sharing of country food was verified by the fieldworker. Households were requested to record country food during the week it was harvested; however, some households reported country food (caribou) harvested in earlier seasons as they consumed it. With the exception of caribou, most country food was consumed when it was harvested. Household weekly reports were consolidated at the end of the study period and data from all households were coded and keypunched for computer analysis.

To ensure the quality and accuracy of data collection, the following measures were instituted. Prior to the research, a special training workshop, including a supervised practicum, was conducted for all survey personnel. Regular household participation in data collection was encouraged by information meetings held in the study communities. Each household was visited by the fieldworker and one of the principal investigators or the research assistant; the purpose and methods of the research were carefully outlined and household cooperation invited. Each participating household was visited weekly by the fieldworker to assist in the record keeping requested for the project. During the study, one of the principal investigators or the research supervisor visited the study community every six weeks to monitor adherence to recording procedures, to advise and encourage the local fieldworker and to spot-check the accuracy of data collected.

\section{Interpretation}

The data from this study refer to a one-year food cycle, lasting from July 1980 to June 1981 , and reflect the biological, economical, climatic and social conditions that prevailed during the research period.

\section{COMMUNITY PROFILE}

Makkovik is a small community in northern coastal Labrador founded in 1896 by the Moravian Church. The community consisted of 347 people in 1981 (Census Canada) and is composed mainly of settler families as well as Inuit families resettled in 1959 from Hebron, farther north. Makkovik's population is distributed in 79 households, of which 61 households participated in the Labrador Food Study by contributing records on their country food harvests from July 1980 to 30 June 1981 . Most households reported their country food harvests regularly during the year, 59 households provided data for 44 weeks or more and the 2 other households joined the study at the end of the fishing season, but then reported regularly. Of the 3172 possible records, 3066 were returned, representing a response rate of $97 \%$. Twenty-four of the records were not returned because the household members were not in the community during the recording weeks. Thus 82 records were not returned by participating households who were in the community or at their summer residence during the week in question. The two households who joined the study late accounted for 28 of these unreported weeks. Because these weeks were in the fishing season, the total quantity of fish would be underreported.

For the purpose of this study, a community census was compiled in July 1980, indicating a total of 333 residents. The 61 households participating in the project included 295 people. Thus 89\% of Makkovik's residents lived or ate with households contributing data to the food study. Participating households ranged in size from one person to twelve people.

\section{HARVEST OF FISH, MAMMALS AND BIRDS FOR HOUSEHOLD} CONSUMPTION

All data are reported as actual recorded amounts. No projections have been made. During the study year harvests of fish, mammals and birds contributed $28397 \mathrm{~kg}$ to the food larders of Makkovik households.

Atlantic cod gadus morhua, Linnaeus, arctic char salvelinus alpinus, Linnaeus, and trout salvelinus fontinalis, Mitchill, were the main fish species caught for household consumption. They contributed $2864 \mathrm{~kg}$ and $2830 \mathrm{~kg}$ respectively to the total quantity of fish reported (Table 1). In Makkovik trout is the term used to refer to both arctic char salvelinus alpinus and brook trout salvelinus fontinalis. Rock cod gadus ogac, Richardson, and salmon salmo salar, Linnaeus, are also important fish sources, providing $1530 \mathrm{~kg}$ and $1030 \mathrm{~kg}$ respectively. Fish harvests provided $30 \%$ of the total quantity of country food reported for household consumption.

Seals contributed $3170 \mathrm{~kg}$, or $11 \%$ of the total quantity of country food produced by Makkovik residents. This relatively low recorded harvest, compared to other species and in view of the harvest level expected from the community (Usher, 1982), suggests that household reports may not indicate all the seals caught and consumed during the study year. Sharing of seal is a regular practice. Households seem not to have recorded seals they caught but distributed or that they received from other families. The sharing of seal meat, much of which occurs when the seals are skinned, would explain the low seal harvest reported in a community generally thought to pursue seals actively. Records of sharing of food were normally made by the producing households and verified with the consuming household by the fieldworker. Since this seal was never taken into the producing household, it may not have been recorded as a gift on its records. The women were mainly the ones responsible for record keeping.

Caribou rangifer tarandus, Linnaeus, contributed the largest quantity of country food, $10960 \mathrm{~kg}$ or $38.5 \%$, to the Makkovik subsistence economy. Other land mammals contributed only a small quantity of food during the study year.

Wild fowl provided $5334 \mathrm{~kg}$ or $19 \%$ of the country food harvest. Of the various species harvested, eider ducks, (common) somateria mollissima, Linnaeus, and (king) somateria spectabilis, Linnaeus, and ptarmigan/grouse, (willow) lagopus lagopus, Linnaeus, (rock) lagopus rupestris, Linnaeus, and (spruce grouse) canachites canadensis, Linnaeus, were the main wild fowl hunted for household consumption, producing 1896 $\mathrm{kg}$ and $1433 \mathrm{~kg}$ respectively. Canada geese, branta canadensis, Linnaeus, and black ducks anas rubripes, Linnaeus, were also important food sources, providing catches of $754 \mathrm{~kg}$ and $527 \mathrm{~kg}$ of food.

Households also reported a harvest of $832 \mathrm{~kg}$ of berries. These include red berries vaccinium sps., blackberries empetrum nigrum, blueberries vaccinium angustifolium, bakeapples rubus chamaemorus and squashberries viburnum edule.

\section{Allocation of Community Harvest}

Household Production of Country Food. The ability of households to gain access to seasonal supplies of country food depends on a number of factors. Hunting and fishing are customarily male occupations, and while females may occasionally go on caribou hunts or fishing, it is usually a male who is the family provider and most active, regular harvester. 
TABLE 1. Total quantity of fish, mammals and birds harvested by all reporting households in Makkovik, July 1980-June $1981(\mathrm{~N}=62)$

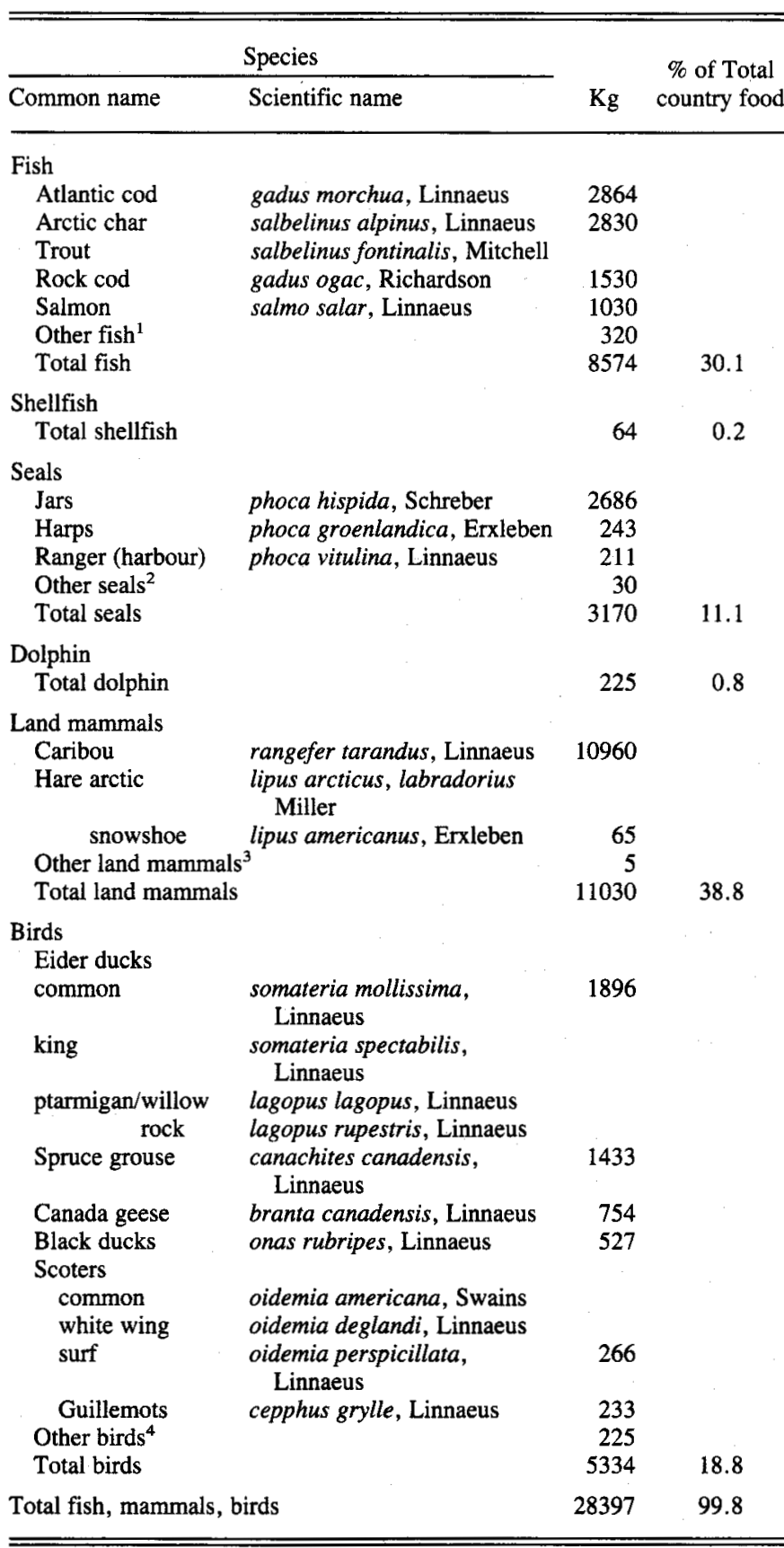

'Other fish include herring culpea harengus, harengus, Linnaeus; capelin mallotus villasus, Muller; smelts osmarus sp., Mitchill; flounder pseudopleuronectus americanus, Walbaum; mackerel scomber scombrus, Linnaeus; turbot reinhardtius hippoglossoides, Walbaum; halibut hippoglossus hippoglossus, Linnaeus; white fish coregonus clupeaformis, Mitchill; redfish sebates marinus, Linnaeus; sculpin coltidae, and squid illex illecebrasus.

${ }^{2}$ Other seals include square flipper erignatuhus barbatus, Erxleben and grey, halichoerus grypus, Fabricius.

${ }^{3}$ Other land mammals include black bear ursus americanus, Pallas; beaver castor candensis, Kuhl; porcupine erethizon eorsatum, Linnaeus and lynx lynx lynx canadensis, Kerr.

${ }^{4}$ Other birds include mergenser: common mergus merganser, Linnaeus; red breasted, mergus serrator, Linnaeus; hooded lophodytes cucullatus, Linnaeus; golden eye: common bucehala clangula, Linnaeus; barrows bucephala islandica, Linnaeus; harlequin duck histrionicus histrionicus Linnaeus; turr (murre tinker) thick billed uria lomvia Linnaeus; common uria aalge, Pontoppidan; razor bill alca torda, Linnaeus; Widgeon mareca americana, Gmel; dovekie (bullbird) plautus alle Linnaeus; and wobby (red-throated loon) gavia stellata, Linnaeus.
Families with a number of adult sons or other adult males (e.g., an unmarried brother) attached to the household have the advantage of several potential harvesters and also a higher demand for food sources than young or smaller families. The absence of adult males in a household often spells hardship and obligates the family to depend on sharing and gifts of food from relatives and friends. Of the 61 households participating in the study, 47 were single families, 8 were extended families and 6 were without an adult male provider. Families with several adult males who were active hunters tended to produce higher household volumes of country food for household consumption, ranging from $256 \mathrm{~kg}$ to $1646 \mathrm{~kg}$, with an average $878 \mathrm{~kg}$, while families without an adult male provider produced among the lowest household volumes, from $41 \mathrm{~kg}$ to $285 \mathrm{~kg}$, with an average $170 \mathrm{~kg}$. A harvest level of $455 \mathrm{~kg}$ (1000 lbs) of country food for the study year was used to distinguish low and high household quantities of country food.

Harvest activities require a heavy capital investment in equipment (e.g., boats, ski-doos), repairs and maintenance, fuel, weapons and ammunition and other gear (e.g., fishing nets, sledges, tents and camping supplies). An active fisherman and hunter must have a "sizable" cash income, usually obtained from the summer fishery, to meet these capital costs. A person's level of income will contribute to the quality and state of repair of equipment used in harvesting activities, which will affect hunting returns; income will also determine the frequency of harvesting activities, as cash is needed to purchase fuel and ammunition.

Households' cash incomes ranged from an estimated $\$ 2500$ for a family consisting of an adult and child to $\$ 62000$ for a family of 12 . The majority of households in the community reported an income below $\$ 25000$ a year; only eight households indicated that their annual income was above this figure. Of the eight households with a relatively high income, only four had substantial harvests of country food, over $455 \mathrm{~kg}$, during the study year. The four other households were headed by shortterm residents.

Full-time employment opportunities are limited in Makkovik and are generally not desired by active, committed fishermen and hunters, who see themselves as fully employed in seasonal subsistence harvesting activities. The main occupation of household heads is tabulated in Table 2 .

TABLE 2. Occupation of heads of households, Makkovik, Labrador

\begin{tabular}{lc}
\hline \hline Occupation & Number \\
\hline Fishing & 12 \\
Seasonal employment: & \\
Fish plant, construction & 15 \\
Full-time & 15 \\
Pensions/social assistance & 10 \\
Self-employed & 4 \\
Manual work & 3 \\
Part-time & 2 \\
\hline Total & 61 \\
\hline \hline
\end{tabular}

Fifteen household heads had full-time employment in Makkovik; nine were long-time residents and six were recent residents, mainly employed in teaching. The nine households with a fully employed household head who was a long-time resident all produced over $455 \mathrm{~kg}$ of country food during the study year; annual household volumes ranged from $459 \mathrm{~kg}$ to $1313 \mathrm{~kg}$ (the highest household volume recorded in the commu- 
nity). The lowest household volumes of country food for the community were reported by the six households headed by employed but recent immigrants; annual household volumes ranged from $29 \mathrm{~kg}$ to $111 \mathrm{~kg}$. Households of long-time residents of Makkovik produced, on average, five times the quantity of country food produced by households of new residents. There were no differences in the application of hunting regulations to the long- or short-term residents of the community.

Knowledge of the landscape, of travel routes that give easy access to hunting areas and of places where game is usually abundant is crucial to the skill that determines whether a hunter or fisherman will make a successful harvest. Hunting and fishing are time-consuming occupations and, as noted above, a source of cash income is important to a hunter's ability to pursue subsistence activities. The households that produced the highest volumes of country food during the study year, over $455 \mathrm{~kg}$, were those headed by a fisherman, hunter, fish plant worker or a householder with full-time employment whose income ranged from $\$ 13000$ to $\$ 24000$ per year. Fully employed householders could accumulate the same volume of country food as fishermen, whose cash income is earned mainly in summer months by having jobs with flexible working hours (e.g., shift work) or that allow extra time off for critical harvesting periods (e.g., in spring for caribou hunts) and by making efficient use of their spare time.

The relationship of income and family size is shown in Table 3. Households with an income of less than $\$ 13000$ recorded significantly less country food than households with larger incomes $(p<0.005)$. Those households of long-term residents with a total income of less than $\$ 13000$ recorded an average of $319 \mathrm{~kg}$, or $59 \%$ of the country food reported by households of long-term residents with incomes of more than $\$ 13000$. The average household production was $629 \mathrm{~kg}$. Smaller families recorded less country food than larger families $(p<.001)$. The number of persons earning income in the household did not significantly influence the amount of country food produced by the household.

TABLE 3. The relationship of income and number of people in the household to quantity of country food reported by households of long-term residents of Makkovik, 1980-81

\begin{tabular}{|c|c|c|c|c|c|}
\hline \multirow[b]{2}{*}{ Income (\$) } & \multicolumn{3}{|c|}{ Number in household } & & \multirow[b]{2}{*}{ Average } \\
\hline & $1-4$ & & $5-10$ & & \\
\hline & \multicolumn{3}{|c|}{ Quantity recorded } & ave $\mathrm{kg}$ & \\
\hline $\begin{array}{l}<13000 \\
>13000\end{array}$ & $\begin{array}{l}13 \\
15\end{array}$ & $\begin{array}{l}258 \\
446\end{array}$ & $\begin{array}{r}8 \\
18\end{array}$ & $\begin{array}{l}417 \\
748\end{array}$ & $\begin{array}{l}319 \\
629\end{array}$ \\
\hline & 28 & 359 & 26 & 646 & 497 \\
\hline
\end{tabular}

Household volumes of $455 \mathrm{~kg}$ or more of country food were harvested by 26 households in the community (43\% of 61 participating households) (Table 4). Of these, four households had fully employed heads whose household income was $\$ 25000$ or greater (see above); 18 householders were fishermen, plant workers or fully employed, with total household incomes between $\$ 13000$ and $\$ 24000$; and four households had incomes less than $\$ 13000$ from fishing, work at the fish plant or part-time employment.

Of the 35 households that produced less than $455 \mathrm{~kg}, 7$ were recent residents in the community. These 7 households had incomes over $\$ 13000$, including 4 over $\$ 25000$.
TABLE 4. The influence of income and size of families on household production of country food in Makkovik, 2 July 1980-30 June 1981

\begin{tabular}{|c|c|c|c|c|c|c|}
\hline \multirow{2}{*}{$\begin{array}{l}\text { Quantity } \\
\text { (kg) }\end{array}$} & \multicolumn{3}{|c|}{ Income } & \multirow{2}{*}{$\begin{array}{c}\text { No. of } \\
\text { households }\end{array}$} & \multicolumn{2}{|c|}{ Size of family } \\
\hline & $<\$ 13,000$ & $\$ 13-24,000$ & $\$ 25,000+$ & & $1-4$ & $5+$ \\
\hline$<455$ & 17 & 14 & 4 & 35 & 25 & 10 \\
\hline$\geq 455$ & 4 & 18 & 4 & 26 & 8 & 18 \\
\hline Total & 21 & 32 & 8 & 61 & 33 & 28 \\
\hline
\end{tabular}

The 26 households producing a large annual harvest of $455 \mathrm{~kg}$ or more included 162 people, or just over half of the community population, and provided two-thirds, $19886 \mathrm{~kg}$, of the total volume of country food harvested by the community. The 35 households producing less than $455 \mathrm{~kg}$ included 133 people, or slightly less than half of the study population of 295 residents, and provided one-third, or $8511 \mathrm{~kg}$, of the total recorded harvest of $28442 \mathrm{~kg}$ of country food. The average per capita country food available for consumption in the 26 households with large harvests, and large families, was almost twice the average amount available in the 35 households with small harvests, and small families: $123 \mathrm{~kg}$ per capita as compared to $64 \mathrm{~kg}$ per capita respectively (Table 5).

TABLE 5. Quantity and per capita rates of household production of country food in Makkovik, 2 July 1980-30 June 1981

\begin{tabular}{|c|c|c|c|c|}
\hline Quantity (kg) & Households & Population & $\begin{array}{c}\text { Total } \\
\text { harvest }(\mathrm{kg})\end{array}$ & $\begin{array}{l}\text { Average per capita } \\
\text { consumption }(\mathrm{kg})\end{array}$ \\
\hline$<455$ & 35 & 133 & 8511 & 64 \\
\hline$>455$ & 26 & 162 & 19886 & 123 \\
\hline Total & 61 & 295 & 28397 & 96 \\
\hline
\end{tabular}

Household Distribution of Country Food. Caribou is the major country food resource on a weight basis obtained by Makkovik residents, followed by fish, birds and seals. The community harvest of these species, however, is not evenly distributed among households. Several social and economic factors governing households' level of harvest were noted above. The families also have taste preferences that could influence the amount of caribou, fish, birds or seals obtained for kitchen use.

The caribou rangifer tarandus, Linnaeus harvest provides the largest volume of a single species to the community food supply, but 4 households reported having no caribou either from harvest or from gifts and 16 households indicated they had less than $50 \mathrm{~kg}$ of caribou during the study year (Table 6). The 4 households with no caribou reported were all short-term residents of the community. Thus 20 households, constituting $33 \%$ of participating households, reported little or no access to caribou meat through either production or distribution. Almost half of the participating households, or 26 families, had access to $200 \mathrm{~kg}$ or more of caribou, with one family estimating its harvest for its own consumption at $864 \mathrm{~kg}$.

Household availability of fish, the second largest game resource harvested by the community, was more evenly distributed, with most families recording between 1 and $200 \mathrm{~kg}$ of fish during the study year; 26 families consumed $1-99 \mathrm{~kg}$ of fish, 22 families reported having $100-199 \mathrm{~kg}$ of fish and 13 families recorded harvests of $200-399 \mathrm{~kg}$ of fish. The largest quantity of fish recorded for household consumption during the study year by a household was $519 \mathrm{~kg}$.

Most households had access to a harvest of birds consisting of 
TABLE 6. Quantities of species consumed by households in Makkovik, 2 July 1980-30 June 1981

\begin{tabular}{|c|c|c|c|c|c|c|c|}
\hline Quantity (kg) & Fish & Shellfish & Seals & Dolphins & Caribou & $\begin{array}{l}\text { Other land } \\
\text { animals }\end{array}$ & Birds \\
\hline 0 & 1 & 54 & 7 & 34 & 4 & 38 & 1 \\
\hline $1-49$ & 10 & 7 & 30 & 26 & 16 & 22 & 29 \\
\hline $50-99$ & 14 & & 12 & 1 & 5 & 1 & 13 \\
\hline $100-149$ & 13 & & 7 & & 6 & & 7 \\
\hline $150-199$ & 9 & & 4 & & 4 & & 3 \\
\hline $200-249$ & 3 & & 1 & & 9 & & 3 \\
\hline $250-299$ & 6 & & & & 6 & & 1 \\
\hline $300-349$ & 3 & & & & 2 & & 2 \\
\hline $350-399$ & 1 & & & & 4 & & 0 \\
\hline $400-449$ & & & & & 1 & & 1 \\
\hline $450-499$ & & & & & 1 & & 1 \\
\hline $500-549$ & 1 & & & & 1 & & \\
\hline$>549$ & & & & & 2 & & \\
\hline
\end{tabular}

less than $100 \mathrm{~kg}$; 42 households indicated that they had $1-99 \mathrm{~kg}$ of birds, 14 households recorded harvests of $100-299 \mathrm{~kg}$ and 4 households reported over $300 \mathrm{~kg}$ during the study year. One household reported having no birds.

Most households recorded having less than $99 \mathrm{~kg}$ of seal meat; 43 households had 1-99 kg, 12 households recorded having $100-249 \mathrm{~kg}$ and 7 households indicated having no seal. The reporting of seal is lower than anticipated (Statistics Canada, 1982). This may be due to sharing of seal prior to its arriving at the household of the hunter. If the sharing occurred on the ice the homemaker in the producing household would have been unaware of the distribution of the seal.

The distribution of game animals among households in Makkovik, shown in Table 6, roughly coincides with the total volume of individual game species constituting the community harvest. Caribou, the country food resource obtained in greatest volume by community hunters, is generally available in sizable quantity to most households. Most families had access to similar volumes of fish, $1-200 \mathrm{~kg}$, and small volumes of birds and seals were common.

Per Capita Availability of Country Food. Data obtained by the Labrador Food Study indicate that the 295 people of Makkovik, constituting the 61 households that contributed country food records for the research, harvested a total of 28397 $\mathrm{kg}$ of meat, fish and birds during the year from 2 July 1980 to 30 June 1981. The average per capita availability of country food based on the total community harvest and population is $96 \mathrm{~kg}$ (Table 5). However, when the per capita availability is calculated on a per household basis, taking into account the quantity of country food produced by that particular household and the number of people sharing the food in the household, the average per capita quantity of country food available is calculated to be $102 \mathrm{~kg}$.

Statistics Canada figures in 1980-81 indicate a national per capita consumption rate of $117 \mathrm{~kg}$ for meat, poultry and fish (Statistics Canada, 1982). Table 7 shows the range of per capita country food available for consumption among participating households in the study.

People in 10 Makkovik households, representing $16 \%$ of the population in participating households, had available for consumption a quantity of country meat, fish and birds close to the national average, $100-124 \mathrm{~kg}$. Nineteen households, with $28 \%$ of the population, had a per capita availability of country food greater than $124 \mathrm{~kg}$, and people in 32 households, representing $56 \%$ of the population, had a lower per capita availability of wild food than the national per capita average consumption of all meat, fish and poultry. Four households, with $6 \%$ of the population, had a per capita rate of less than $25 \mathrm{~kg}$. The highest per capita availability of country food, over $250 \mathrm{~kg}$, occurred in 2 households. Thus members of slightly less than half (44\%) of the households participating in the study had a per capita availability of country food equal to or higher than the national average of all meat, fish and poultry.

TABLE 7. Per capita availability of country food in participating households at Makkovik, 2 July 1980-20 June 1981

\begin{tabular}{ccccc}
\hline \hline Kg per capita & $\begin{array}{c}\text { Number of } \\
\text { households }\end{array}$ & $\begin{array}{c}\text { \% of } \\
\text { households }\end{array}$ & $\begin{array}{c}\text { No. of individuals } \\
\text { in household }\end{array}$ & $\begin{array}{c}\text { \% of } \\
\text { population }\end{array}$ \\
\hline$<25$ & 4 & 6.6 & 19 & 6.4 \\
$25-49$ & 11 & 18.0 & 47 & 15.9 \\
$50-74$ & 11 & 18.0 & 73 & 24.7 \\
$75-99$ & 6 & 9.8 & 27 & 9.2 \\
$100-124$ & 10 & 16.4 & 48 & 16.3 \\
$125-149$ & 6 & 9.8 & 33 & 11.2 \\
$150-174$ & 3 & 4.9 & 15 & 5.1 \\
$175-199$ & 4 & 6.6 & 16 & 5.4 \\
$200-224$ & 3 & 4.9 & 10 & 3.4 \\
$225-249$ & 1 & 1.6 & 1 & 0.3 \\
$250-299$ & 2 & 3.3 & 6 & 2.0 \\
Total & 61 & 99.9 & 295 & 99.9 \\
\hline \hline
\end{tabular}

The average per capita availability of each species by longand short-term residents of Makkovik is summarized in Table 8. The total per capita availability of country food to long-term residents was significantly more than for short-term residents. This relationship was also true for both seal and caribou.

TABLE 8. Average per capita availability of country food to long- and short-term residents of Makkovik

\begin{tabular}{lcc}
\hline & \multicolumn{2}{c}{ Per capita availability } \\
\cline { 2 - 3 } Species & $\begin{array}{c}\text { To short-term } \\
\text { residents }(\mathbf{k g})\end{array}$ & $\begin{array}{c}\text { To long-term } \\
\text { residents }(\mathrm{kg})\end{array}$ \\
\hline Fish & 17.8 & 32.6 \\
Shellfish & 0.0 & 0.6 \\
Seal & 4.2 & $11.7^{*}$ \\
Dolphin & 0.3 & 0.8 \\
Caribou & 29.0 & $41.4^{*}$ \\
Bird & 11.2 & 21.3 \\
Total country meat & 62.7 & $109.5^{*}$ \\
\hline
\end{tabular}

*Significant at $\mathrm{p} \leq 0.01$.

\section{SUMMARY}

During the study year participating households harvested $28397 \mathrm{~kg}$ of country mammals, fish and wild fowl and $832 \mathrm{~kg}$ of berries from their surrounding environment. Caribou, rangifer tarandus, Linnaeus contributed the largest quantity, $10960 \mathrm{~kg}$. Fish harvests amounted to $8574 \mathrm{~kg}$ and wild fowl contributed $5334 \mathrm{~kg}$. The quantity of seals recorded, $3170 \mathrm{~kg}$, appears to be an underestimate of the expected level of harvest by the community. Other marine mammals such as dolphin, white-beaked lagenorhachus albirostris, Gray, white-sided lagenorhychus acutus, Gray, and other land mammals such as rabbit, arctic hare lipus arcticus, labradorius, Miller, snowshoe hare lipus americanus, Ereleben, did not contribute greatly to the local economy during the study year.

Twenty-six of the 61 households, representing 54\% of the population, harvested more than $455 \mathrm{~kg}(1000 \mathrm{lbs})$ of mammals, 
fish and birds. Most of these households contained five or more people.

Caribou, rangifer tarandus, Linnaeus harvest provides the largest volume of a single species to the community food supply. However, $32 \%$ of the households had little or no access to caribou ( $<49 \mathrm{~kg}$ ) either by production or distribution during the year. The harvests of both fish and birds were more evenly distributed among the households. Low quantities of seal were recorded. Thirteen percent of households reported no seal during the study year. Thirty households, representing $44 \%$ of the population, harvested a per capita volume of country mammals, birds and fish close to or above the national average for fish, meat and poultry. Four households, with $6 \%$ of the population, had a per capita availability of less than $25 \mathrm{~kg}$. Two households reported a per capita availability of over $250 \mathrm{~kg}$. Two households had a per capita volume of over $250 \mathrm{~kg}$.

The data reported in this study record one country food cycle, July 1980-June 1981, only. Because of both the short- and long-term variations in the availability of many boreal and arctic species, general inferences from the recorded information is risky. Hunting and gathering of food are important for most families in Makkovik. Their society had a central hunting tradition, and food preferences and habits are important to their cultural heritage. Food is an integral part of a way of life in Makkovik, and foods have meaning that not only relates to their eating but to the procurement, distribution and preparation as well.

\section{ACKNOWLEDGEMENTS}

Financial support for this research was received from the Donner Canadian Foundation, Health and Welfare Canada and Canada Employment and Immigration. The authors acknowledge the assistance of Clara Michelin, research assistant, Carol Dyson, fieldworker, Donna Green, computer programmer, Carol Brice Bennett, research assistant, and Diane Saunders, Beatrice Decker, Gem Cornick and Jennifer Dawe for their help.

\section{REFERENCES}

STATISTICS CANADA. 1982. Apparent Per Capita Food Consumption in Canada. Cat. No. 32-226.

USHER, P. 1982. Renewable Resources in the Future of Northern Labrador Report to the Labrador Inuit Association, Nain, Labrador. 